\title{
The Influence of Management Effectiveness, Work Culture, Trust, and Engagement, towards Work Effec- tiveness of Employees PT. Megapolitan Developments Tbk
}

\author{
Dewi Tridasawarsa ${ }^{1}$, Ma'ruf Akbar ${ }^{2}$ and Thamrin Abdullah ${ }^{3}$ \\ \{dewitridasawarsa@yahoo.co.id ${ }^{1}$ \} \\ Universitas Negeri Jakarta, Jakarta, Indonesia ${ }^{1,2,3}$
}

\begin{abstract}
This research was aimed to measure and analyze the influence of the effectiveness of management, work culture, trust, and engagement, towards work effectiveness of employee. The research was conducted at PT. Megapolitan Developments Tbk. This research was conducted to 193 respondents as the samples out of 650 population from all branch office at Jakarta.This research used the quantitative approach with path analysis. The result that: (1) there was positive and significant influence between effectiveness of management towards trust; (2) There was positive and significant influences between effectiveness of management towards work effectiveness; (3) There was positive and significant influences between effectiveness of management towards engagement; (4) There was positive and significant influences between work culture towards trust; (5) There was positive and significant influences between work culture towards engagement; (6) There was positive and significant influences between work culture towards engagement; (7) There was positive and significant influences between trust towards work effectiveness; (8) There was positive and significant influences between engagement towards work effectiveness.
\end{abstract}

Keywords: effectiveness of management, work culture, trust, engagement, work effectiveness.

\section{Introduction}

Many factors cause employee work to be ineffective, especially in a family-business company [1], where there is intense competition within the family environment itself which leads to power struggles that have an impact on many conflicts, intrigue, and high nepotism in every internal business process factor [2]. The main problem is that employees feel the object of this research is long and layered bureaucracy, having leaders comes from nepotism [3], elements of likes and dislike of directors / management are very thick, making employees feel anxious [4], who has an impact on high employee turnover that exceeds the normal rate and the high rate of employee absence [5].

Regarding the character of family companies that cause poor conflict management [6], employee turnover [7] and high employee absence rates [8], researchers see the ineffectiveness of employee work in realizing the planned work target. The following is a graph of employee turnover and absence: 
Employee Turn over

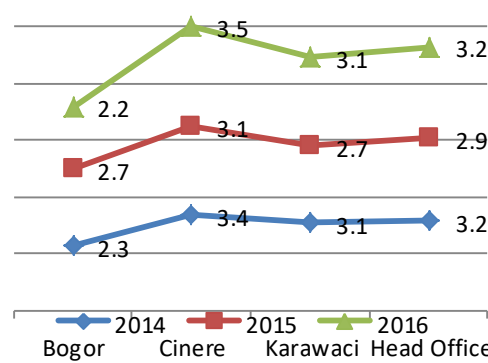

Resources : Human capital divisio
Absence Presentation

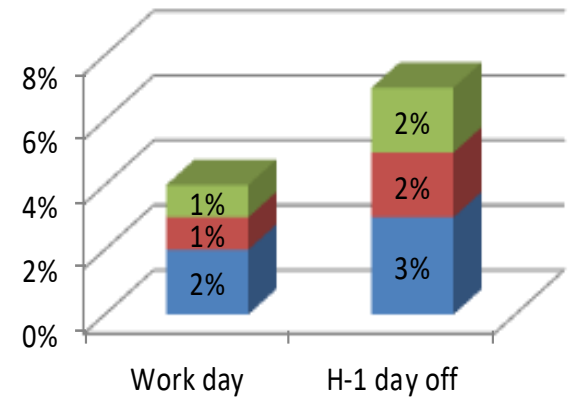

Sick No notice $\square$ Leave

The problem that is often faced besides the turnover of $3 \%$ is employee absence on certain days [9], namely H-1 day off. Some employees choose not to attend work, especially reasoned sick and not present without any information [10].

Besides that, work culture is an important factor in realizing employee work effectiveness. Work culture is based on the values that are owned by the Company which are processed in such a way as new values that become expected Management attitudes and behaviors in an effort to face new challenges [11]. Work culture is important because it helps employees to understand their respective roles in achieving organizational goals or objectives (Berardi, 2009), while also providing boundaries of ethical codes of conduct to determine which ones can be done, which cannot be done [12].

Trust is the feeling of trust and confidence of employees in management and companies in managing their business. Trust in the organization is important [13]. Organizations that have high trust from employees are easier to carry out their operational activities [14]. With high trust, a commitment to carry out activities more strongly, the risk of internal intrigue is smaller, productivity and performance of employees and organizations ultimately increases [15]. Trust in the company has a strong positive impact on emotional commitment employee [16].

Engagement is the degree to which an employee is able to commit to an organization and the results of that commitment are determined by how they work and the length of their work [17], positive attitudes employees have towards the organization and value values in it [18]. Employees who are engaged are aware of the business context and work with fellow employees to improve work performance for the benefit of the organization [19].

\section{Method}

This research uses quantitative methods and is analyzed by path analysis. Samples were taken using a homogeneous population of 193 employees from a population of 650 people. The number of samples is determined by the Slovin formula with a 5\% error margin of 130 people. 


\section{Result}

In this study the result is that there are direct and significant effects of each exogenous variable on other exogenous variables as well as on endogenous variables with the path analysis structure equation as follows:

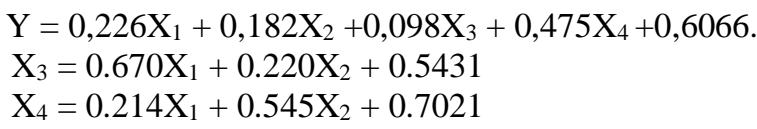

\section{Picture 4. Result}

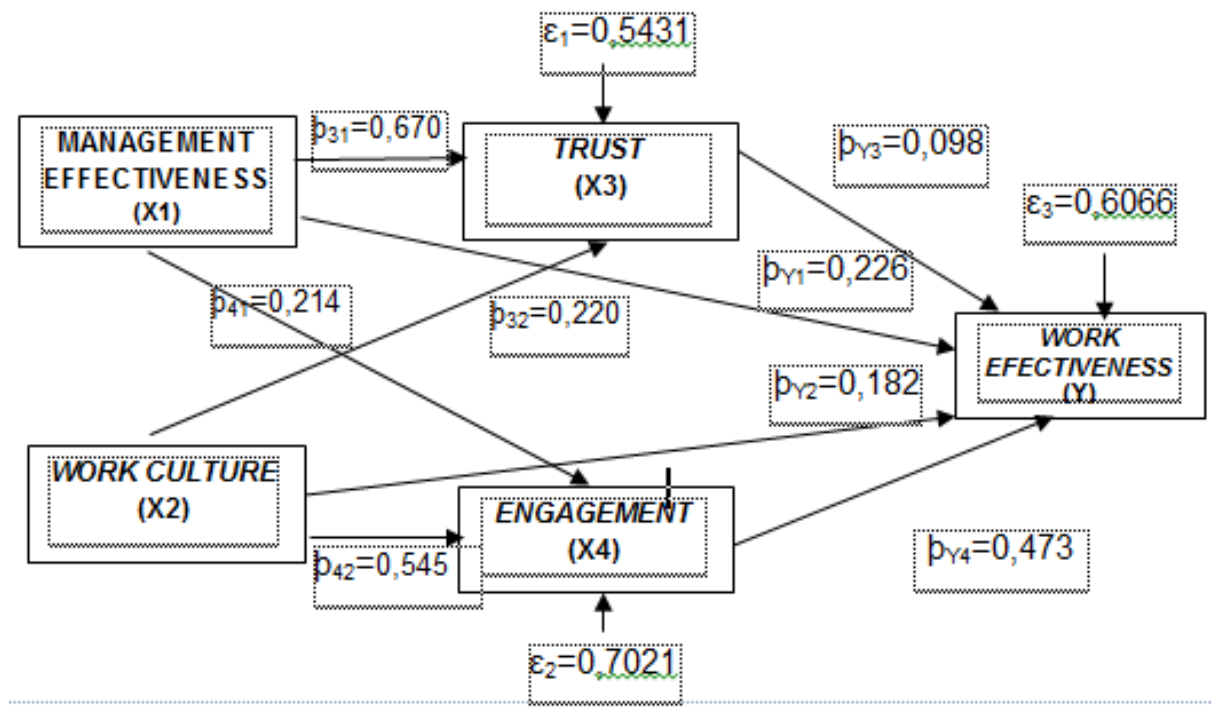

\section{Discussion}

Based on the findings in this study it was stated that management effectiveness (X1) has a direct effect on trust (X3). This is in line with Luthans' theory, that human resources are successful if management is able to establish information and communicate with each other, pay attention to and empower employees, resolve conflicts, and trust their organization [20] and align that leadership effectiveness in management affects employee trust [21].

Based on the findings, management effectiveness (X1) has a direct effect on work effectiveness (Y). This is in line with the research conducted by Genesys, that Management Effectiveness can encourage employees to work prioritizing priorities, and emphasize effective leader behavior and go directly to operations [22]. Based on the findings stated that management effectiveness (X1) has a direct effect on engaement (X4). This is in line with Medlin's theory which says that the impact of effective management will produce employees who are more involved in their work [23], and in line with research conducted by Hasan that effective leaders will produce employees who are bound. 
Based on the findings, work culture (X2) actually has a direct effect on trust (X3). This is in line with Rollins' theory which says Work culture that consistently produces employee confidence in management and companies [24]-[28], as well as employee job satisfaction [29], on company performance and employee performance. Based on the findings in this study it was stated that work culture (X2) has a direct effect on engagement (X4). This is in line with Schaufeli's theory that positive work culture has an impact on employees who are happier, healthier and more productive [30] and work culture that brings flexibility will result in employees more comfortable working [31].

Based on the findings, it was stated that work culture (X2) has a direct effect on work effectiveness (Y). This is in line with Marc's research on employee work effectiveness based on the development of work capabilities [32], [33], and the effect of teamwork effectiveness on personal work effectiveness [34]. Based on the findings, it can be stated that Trust (X3) has a direct effect on Work effectiveness (Y). This is in line with Bowen's research regarding management sovereignty in providing trust to employees [35], while trustworthy management can make employees work more performably. Based on the findings, it was stated that Engagement (X4) has a direct effect on Work effectiveness (Y). This is in line with Schaufeli's theory regarding the impact of engagement on employee work output [30], and the influence of engagement on organizational effectiveness [17], and the effect of engagement on employee job satisfaction [36].

\section{Conclusion}

Based on the results of the research, data analysis and hypothesis testing, it was concluded that there were direct and significant effects of Management Effectiveness, Work Culture, Trust and Engagement on Employee Work Effectiveness with the most influential variable Trust. In family companies, trust is the biggest foundation in the effectiveness of all jobs. Management will not be effective if it acts inconsistently, makes decisions based on like or dislike, recruits high-ranking officials based on nepotiseme, the number of family conflicts of interest that influence decision making, the amount of intrigue and conflict that results in employee distrust of management. Management is also obliged to delegate and make deliberation decisions so that employees feel more engaged, and create a positive and conducive work culture so that employees can work comfortably and effectively.

\section{Refferences}

[1] R. Basco and M. J. Pérez Rodríguez, 'Ideal types of family business management: Horizontal fit between family and business decisions and the relationship with family business performance', J. Fam. Bus. Strateg., 2011.

[2] M. Visio, 'Nepotism practices and the Work-Family interface', in Nepotism in Organizations, 2012.

[3] K. Mutlu, 'Problems of nepotism and favouritism in the police organization in Turkey', Policing, 2000.

[4] R. G. Jones, Nepotism in organizations. 2012.

[5] J. Wijnmaalen, L. Heyse, and H. Voordijk, 'Organisational commitment and turnover intentions in humanitarian organisations', Int. J. Hum. Resour. Dev. Manag., 2016.

[6] B. Villalonga and R. Amit, 'How do family ownership, control and management affect firm value?', J. financ. econ., 2006.

[7] A. H. De Lange, H. De Witte, and G. Notelaers, 'Should I stay or should I go? 
Examining longitudinal relations among job resources and work engagement for stayers versus movers', Work Stress, 2008.

[8] E. Gosselin, L. Lemyre, and W. Corneil, 'Presenteeism and absenteeism: Differentiated understanding of related phenomena', J. Occup. Health Psychol., 2013.

[9] E. Demerouti, P. M. Le Blanc, A. B. Bakker, W. B. Schaufeli, and J. Hox, 'Present but sick: A three-wave study on job demands, presenteeism and burnout', Career Dev. Int., 2009.

[10] C. L. Cooper and P. Dewe, 'Well-being-absenteeism, presenteeism, costs and challenges', in From Stress to Wellbeing, 2013.

[11] R. C. Hoffman, F. M. Shipper, J. A. Davy, and D. M. Rotondo, 'A cross-cultural study of managerial skills and effectiveness: New insights or back to basics?', Int. J. Organ. Anal., 2014.

[12] H. Yousofpourfard, 'Cultural Intelligence: A new approach to manage teamwork in culturally diverse teams', ProQuest Diss. Theses, 2010.

[13] B. J. Avolio, W. L. Gardner, F. O. Walumbwa, F. Luthans, and D. R. May, 'Unlocking the mask: A look at the process by which authentic leaders impact follower attitudes and behaviors', Leadership Quarterly. 2004.

[14] J. K. Muhl, Organizational trust: Measurement, impact, and the role of management accountants. 2014.

[15] A. Tirelli and S. C. Goh, 'The relationship between trust, learning capability, affective organisational commitment and turnover intentions', Int. J. Hum. Resour. Dev. Manag., 2015.

[16] R. E. de Vries, A. Bakker-Pieper, and W. Oostenveld, 'Leadership = communication? The relations of leaders' communication styles with leadership styles, knowledge sharing and leadership outcomes', J. Bus. Psychol., 2010.

[17] S. L. Albrecht, A. B. Bakker, J. A. Gruman, W. H. Macey, and A. M. Saks, 'Employee engagement, human resource management practices and competitive advantage: An integrated approach', Journal of Organizational Effectiveness. 2015.

[18] M. A. Drescher, M. Audrey Korsgaard, I. M. Welpe, A. Picot, and R. T. Wigand, 'The dynamics of shared leadership: Building trust and enhancing performance', J. Appl. Psychol., 2014.

[19] F. Amagoh, 'Leadership development and leadership effectiveness', Manag. Decis., 2009.

[20] S. M. Norman, B. J. Avolio, and F. Luthans, 'The impact of positivity and transparency on trust in leaders and their perceived effectiveness', Leadersh. Q., 2010.

[21] L. Gardner, 'Effective Organizations for Management Effectiveness: Another View of Protected Areas Development', Eff. Organ. Manag. Eff. Another View Prot. Areas Dev., 2012.

[22] A. L. Tucker and S. J. Singer, 'The effectiveness of management-by-walking-around: A randomized field study', Prod. Oper. Manag., 2015.

[23] A. J. Mitchell et al., 'Prevalence of Depression, Anxiety, and Adjustment Disorder in Oncological, Haematological, and Palliative-Care Settings: A Meta-Analysis of 94 Interview-Based Studies', Lancet Oncol., vol. 12, no. 2, pp. 160-174, 2011.

[24] T. Hamada, 'The Cultural Environment of International Business', Anthropol. Work Rev., 1985.

[25] S. A. Sackmann, 'Culture and performance', in The Handbook of Organizational Culture and Climate, 2011.

[26] S. Kanungo and V. Jain, 'Organizational culture and e-government performance: An 
empirical study', Int. J. Electron. Gov. Res., 2011.

[27] F. Shahzad, 'Impact of Organizational Culture on Organizational Performance : An Overview', Interdiscip. J. Contemp. Res. Bus., 2012.

[28] A. N. William, 'Employee motivation and performance', Bus. Manag., 2010.

[29] S. Dev and S. Sengupta, 'The impact of work culture on employee satisfactionempirical evidence from the Indian banking sector', Int. J. Hum. Resour. Dev. Manag., 2017.

[30] W. B. Schaufeli, A. B. Bakker, and M. Salanova, 'The measurement of work engagement with a short questionnaire: A cross-national study', Educ. Psychol. Meas., 2006.

[31] C. Timms et al., 'Flexible work arrangements, work engagement, turnover intentions and psychological health', Asia Pacific J. Hum. Resour., 2015.

[32] G. Andrews and M. Russell, 'Employability skills development: Strategy, evaluation and impact', High. Educ. Ski. Work. Learn., 2012.

[33] DEST, 'Employability Skills for the Future', Educ. Train., 2002.

[34] J. Mathieu, T. M. Maynard, T. Rapp, and L. Gilson, 'Team effectiveness 1997-2007: A review of recent advancements and a glimpse into the future', Journal of Management. 2008.

[35] R. Cropanzano, D. E. Bowen, and S. W. Gilliland, 'The management of organizational justice', Academy of Management Perspectives. 2007.

[36] M. M. Mackay, J. A. Allen, and R. S. Landis, 'Investigating the incremental validity of employee engagement in the prediction of employee effectiveness: A meta-analytic path analysis', Hum. Resour. Manag. Rev., 2017. 